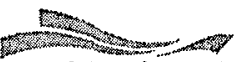

展望・解説

\title{
ニ次元スカラー量分布の画像表示*
}

吉田豊 明**

\section{Image Display for Plane Distribution of Scalar Quantity}

\author{
Toyoaki YosHIDA
}

\section{1. まえがき}

コンピュータグラフィックス (CG 画像処理・ 表示) は，科学・工業の研究開発に打いても，計 画・解析・広報等の手段として大変有用であるた め, 近年あらゆる分野で適用されつつあり，ぼう 大な量のデータを的確に迅速に処理して, 現象を 解明するには，今や必須であるとい去らう。流れ に伴う物理量を扱う者にとっては，各種の直接的 な流れの可視化法を適用できないようなケースに も，CGによって疑似的に流れを表現できるとい ら点できわめて意義深い。

画像処理・表示の系統的で高度な理論の解説, 日進月歩するこの方面の機器の紹介等は他に譲る として，ここでは，実験，数值計算で得られるス カラー量のマトリクス状の分布を二次元分布の画 像として表示するといら基本的な作業のソフトウ ェアについて，主として筆者の実施例をもとに， 概説する。閣知の上らに画像データは点数が多い ので，各々の点に関して施す数学的処理をできる だけ簡単にしないと画像全体の処理時間が大変長 くなるが，一方ではオリジナルデータの性質を忠 奏に表示するよら配虑しなければならない。

\section{2. 值と濃淡・色の対応}

着目する領域内の值の最大值と最小值を両極端 とし，全点の值を表示するのに，值と濃淡・色を どのように対応させるのか, 階調の数をいくつに
するのかは，最も基本的な問題である。濃淡・色 の割当てについては，問題とする值の範团を比例 的に抎大，縮小乙て，装置の具備する階調数ので さるたけ多くを表わすようにするのが一般的であ る。ただし扱う画像の数が複数で，特定のパラィ 一タの違いKよる差暴を考察する場合は, 全デー タの最大值と最小値を雨極端とすべきである。值 の桁数の範囲が広い場合は，対数をとった上で比 例的に割当てるとよい。またある基準值からの微 小な変化を問題とする場合は，基準值を引いた変 化分のみを割当てるべきである。階調の数につい ては, 連続的階調と階段状階調の 2 種がある。両 者のはっきりとした境界はないが，32階調（5ビ ット）以上で裴示はかなり連続的な感じとなる。

濃淡よりも色分けの方が目で識別できる階調数 は多く，かつ容易に大小関係が理解できる。しか し色分けの階調でも隣接する階調の境界に等高線 を入れなければ，16種程度が限界で，それ以上で は複雑で判読できない領域の生じる場合が多い。

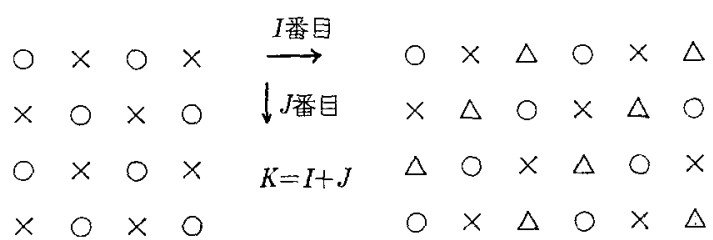

$L=\mathrm{MOD}(K, 2)$

$L=0 \rightarrow \mathrm{O}$

$L=\mathrm{MODD}(K, 3)$

$L=0 \rightarrow 0$

$I=1 \rightarrow \times$

$L=2 \rightarrow \triangle$

(a) 2 色合成 (b) 3 色合成 
濃淡の表示では小さい值を暗く, 大 きい值ほど明るくするのが一般的で あり，場合によっては反転させる。 また干渉縞写真のように明暗の変化 を繰返して，階調の数を増す方法も ある。色表示では，選択できる色の 数は土夫によって実用上いくらでも 多くとれる。すなわち用いている装 置の表示できる色の数が, 例壳ば 8 色のよらに比較的少ない場合でも， 各点の色を規則的にモザイク状に配 置すれば，基本色と異なる色調が得
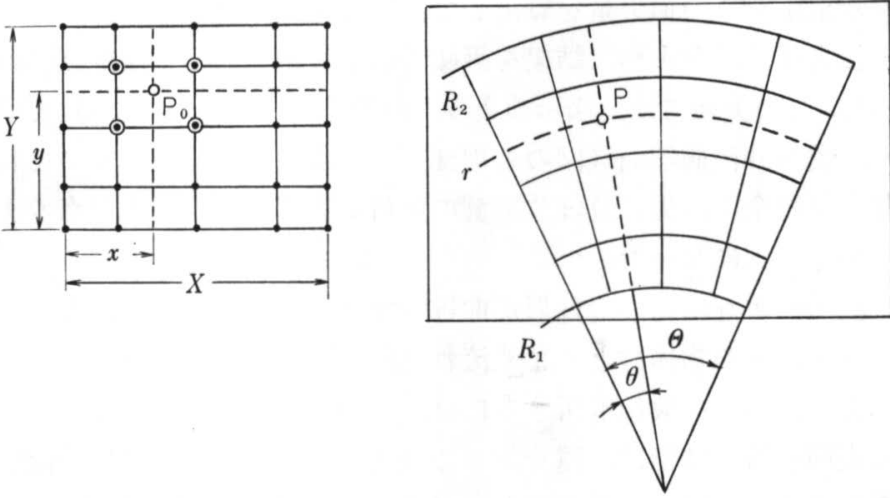
(a)データファイル配置

(b)画像

図 2 極座標配置データの色塗り

られる。図 1 (a), (b) に最も簡単な 2 種の配置 例を示す。(a)は 2 種，(b)は 3 種の色を上下左右交 互に配置する方法であり, 図中に示すような簡単 なアルゴリズムで，きわめて多くの色ファイルが 得られる。すべての組合せについてあらかじめ色 見本を作っておくとよい。色表示に拈いて普遍的 とみなされる配色はないが, 虹の配色に近づけ, 赤系を大きい值の方に, 紫系を小さい值の方に対 応させるのが視覚的に受け入れ易い。濃淡の場合 と同様に, 適当な数の色調の組合せを絽返しても よい。

作成した画像を写真，プリンターで記録する場 合は，ディスプレイ上の画像の色調を忠実に再現 しない場合が多い。また標準の NTSC 方式ビデ オ信号で記録する場合は, 一般にオリジナル画像 より空間分解能, 周波数応答等が悪いので画質が 低下する。したがって，いずれにしても結果の画 として満足できるような色調, 階調で画像表示を することが重要である。

\section{3. 色塗り, 補間}

実験, 数值計算で得られるスカラー量の検査面 （二次元）に拈けるデータ群は，ビデオ信号の場 合を除いて，一定の配置を構成する格子線の交点 上に拈ける值の集合である。これを画像表示する には, 問題とする領域内のすべての画素の值を決 めねばならないから, 格子点にない大部分の画素 については, 近傍にある格子点上の值から補間し て, その值を求める必要がある。格子 線が直線 で, 直交座標系であるような多くの場合は, 画素
と近傍の格子点との幾何学的関係は簡単である が, 格子線が円弧と直線からなる極座標配置とか, 曲線群からなる配置のような場合には, 幾何学的 関係を表わすのに工夫が必要となる。

図 2 (a), (b) は極座標配置に和ける塗色法の一 例を模式的に示す。画像表示の幾何形状は扇形で あるが，データ群は二次元状のマトリクスである 場合に，画像内の任意の位置 $\mathrm{P}$ とデータファイル 内の対応する補間位置 $\mathrm{P}_{0}$ との関係は, 次式を満 たす; $\theta / \Theta=x / X,\left(r-R_{1}\right) /\left(R_{2}-R_{1}\right)=y / Y$ 。す なわち点 $\mathrm{P}$ の $r, \theta$ を求めれば, $R_{1}, R_{2}, \theta, X, Y$ は 既知であるから, 点 $\mathrm{P}_{0}$ の位置 $x, y$ がわかる。し たがって, 点 $\mathrm{P}_{0}$ の值 (=点 $\mathrm{P}$ の值) は, 近傍の データ（例觉ば二重丸印のデータ）から適当な補 間法（後述）で決められる。図３はガスタービン の実機要素試験体に抽いて, 円環状に配置された 静翼の後流で, 2 枚の翼の後流を含む扇形の検査 面内の全圧をピトー管で測定し, 翼列の前流にお

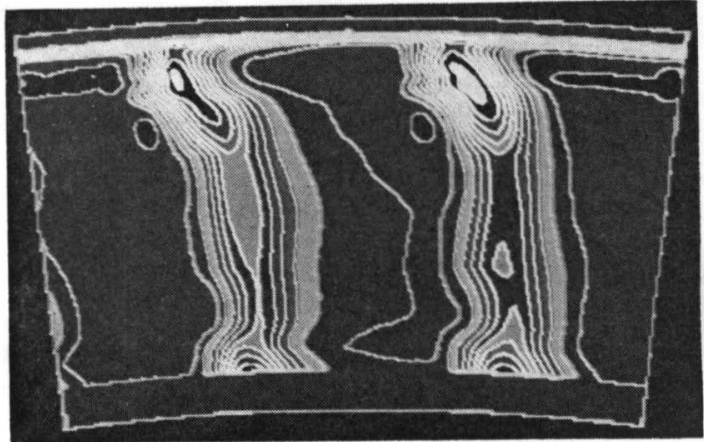

図 3 画像表示の一例 (タービン静翼後流の全圧損 失分 才 
ける全圧からの損失量を算出して，無次元值（全 圧損失係数）を求めた結果を画像表示した例であ る1”。この実験では，図示のよらな画像表示によ り, 翼の外径側端面（図の外周部）から吹出す冷 却空気の全圧損失に及ぼす影響の解析が大变容易 でかっ周到になった。

翼形の上らに物体の外形が曲線の集まりからな る場合，その物体をとりまく流れとか，物体内の 応力, 温度等を数值解析するには, 外形線に沿っ て表面近傍では密に，遠く離れるほど間隔をおい て曲線または短い直線のつなき（折線）で配置さ れる格子線群と，これらに比較的大きな（垂直に 近づく）角度で交わる格子線群とで，計算格子を 形成することが多い。図 4（a）はこのような場合 の一例を模式的に示す。格子線群はそれぞれ $K$ で番号付けられる組で配置され，格子点の $x, y$ 座標（Cartesian）上その位置に括ける值（例免 ば, 密度, マッ八数) は, $x(J, K), y(J, K)$, $D(J, K)$ で与えられる。この場合の塗色法で容易 に思いつく方法の一つは，図(b) に示すよらな 4 点の格子点で形成される領域を単位要素とし, 図 (a)k示すよらに番号付计 ( $L: 1$ 番目から $(J E-$ 1) $\times(K E-1)$ 番目まで, $L 1 E=J E-1, L 2 S=$ $J E, L 2 E=2(J E-1)$ ，など）を施して，単位要 素毎に順次色塗りを行う方法である。ここでL番 目の要素の $J, K$ は次の簡単な式で与えられる。 $J=M O D(L,(J E-1))$, ただし $J=0$ なら $J=J E$ $-1, K=I F I X((L-1) /(J E-1))+1$ 。したがっ て要素 $L$ の頂点の座標之值は容易に読み出され る。さて要素を四边形とみなし，その内部または 辺上にある画素を塗色するには，図(b)のように画 像座標に执いて要素 $L$ を内部に含む長方形を考 え, 長方形内の全点について一点毎に要素 $L$ の か外かを判定して，内点であれば，その点の座標と 4 頂点の坐標・值とから適当な補間法に上りその 点の值を定め（塗色し），外点であれば何むしな い,とすればよい。内外点の判定法には，様々な 方法が工夫されよら。一つの簡単な方法は, 図(c) に示すよらにP点と頂点とで形成される四つの三 角形の面積和が四辺形の面積に等しければ内点, 前者が大きければ外点である，とするものであ る。なお当然のことながら，オリジナルデータの $x, y, D$ は，適当な段階で画像表示に適した值に 変換 (スケーリング) する必要がある。

口絵 3 に示す例は航空機の翼形まわりの流れを ナビェ・ストークスコード NSFOIL ${ }^{2)}$ により粘性 解析した結果のうち，マッ八数分布の一例をここ に述べた方法で画像表示したものであり, $J=125$ ， $K=51$ の格子配置で, 距離の逆数補間（図 5 参照） により塗色したものである。

値の既知な点を頂点とする四辺形内の点（画 素）の值を定めるのに様々な補間法がある。画像 表示をするためのデータ群は, もともと充分な数 の点数がなければならないが，逆に多くあれば補 間の方法は何であろらとも結果としては大差がな いので，簡単なアルゴリズムを用いればよい。実 際には，画像表示をしてみて，格子線の配置がわ かるよらな規則性のある縞，段差などが現われた ら，その塗色法は適切でないと判断されるが，才 リジナルデータにすでにある特質かもしれないの

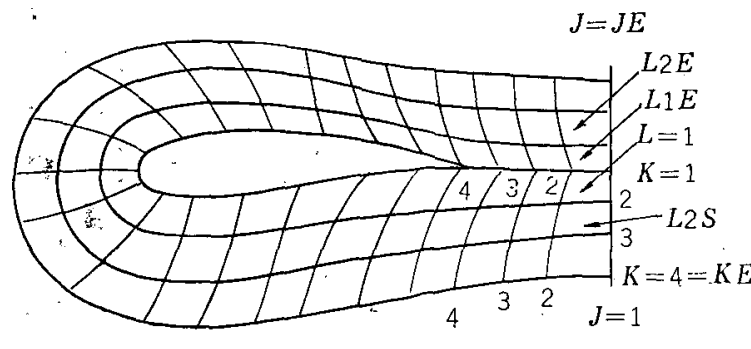

(a)格子配置亡番号付

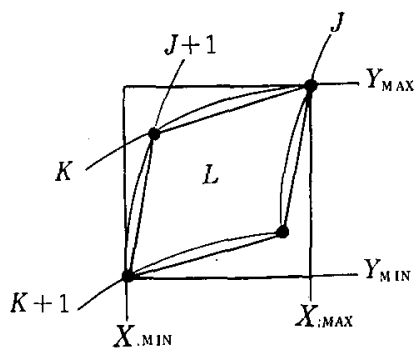

(b)単位格子の画像配置

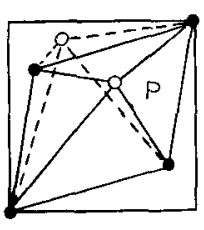

(c)内外点の半定

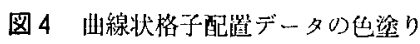


で, 慎重な検討が必要であ る。

図 5 に，著者が央施例を知 る数種の補間法を揭げた。内 挿点数が少ないほど簡単な方 法でよいが，ある程度多くて も(縦横に $20 \sim 30$ 点=数百点) 比較的なめらかな分布が得ら れるような方法として(e)，(f) がある。また 4 ケの格子点か らなる四辺形が，長方形，扇 形でない場合にも，(c),(d)の 方法は適用できる。さらに綎 と横方向で格子線の配置密度 が著しく異なる場合には，そ れぞれの方向に対して適切な 別の補間法を採用するのがよ い。

\section{4. 平滑化 (スムージング)}

画像信号に和ける分解能の 不足, ノイズ，実験・計算に 特ける各種䛊差などのため に，画像がモザイク状であっ

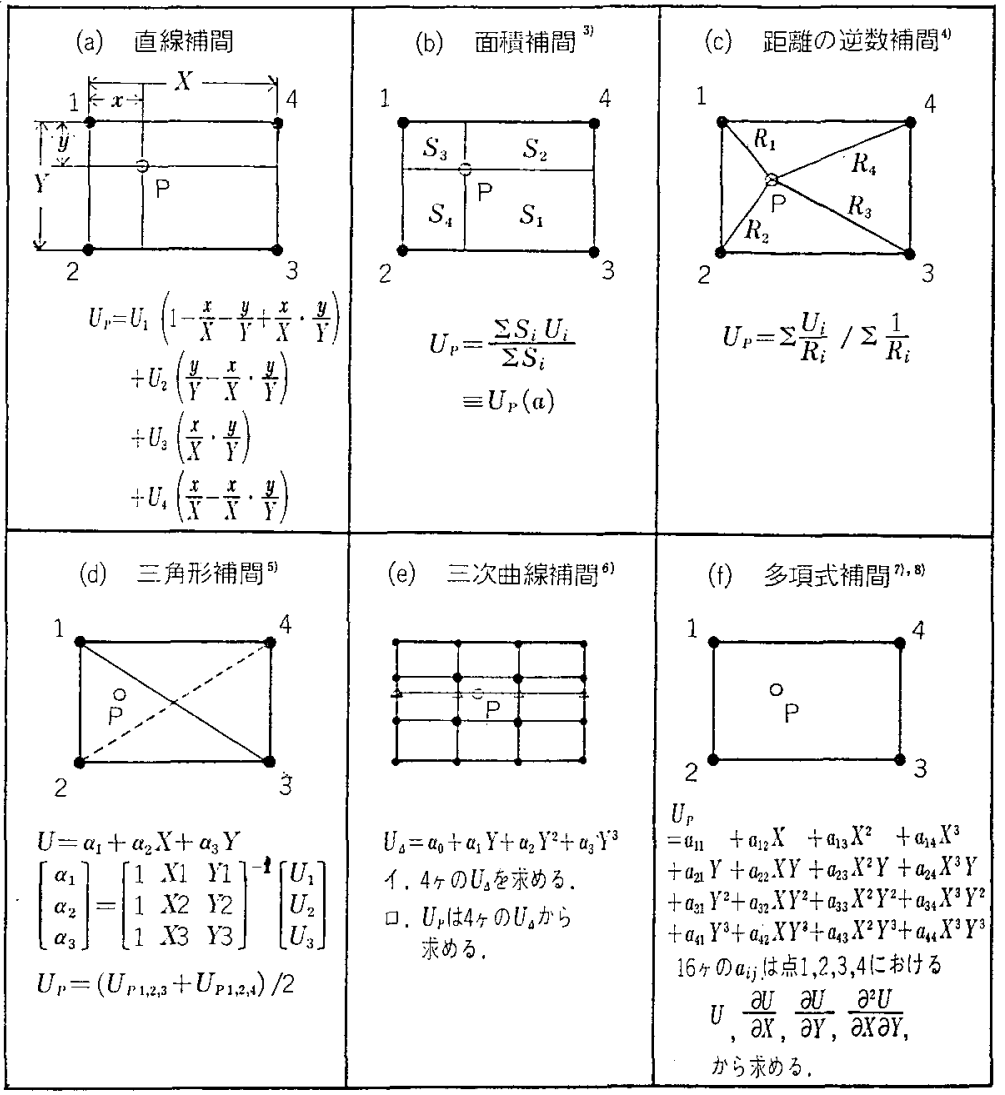

图 5 画像構成のための各種補間法

データのために確保できるメモリ一容量に依存す るが，基本的な概念としては，画像全点の一点毎 に，その値と近傍の複数の点の值との相加平均を 算出し, 全点終ったら, 処理後のデータをオリジ ナルデータの有していた最大值と最小值の範囲に 一致するようにスケーリングする，という手続き である。この処理は満足すべき分布が得られるま で繰返すことができる。また着目点に重みをつけ

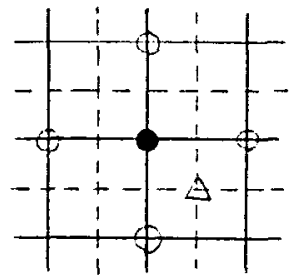

(a)

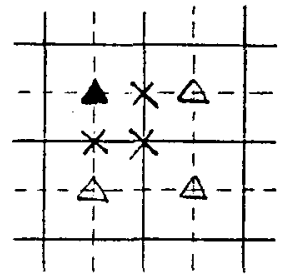

(b)

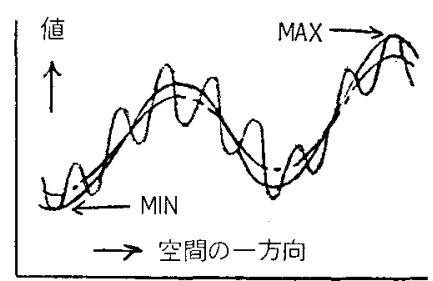

(c)

図 6 画像の平滑化の概念 
る加重平均とした方がよい場合もあり，特に画像 データでない枠線とか文字の部分に処理を施さな いようにしたいとき，有用である。

図6に, メモリ一容量が一画面分しかないとき の平滑化の概念 (a) (b) と, 平滑化, スケーリン グに拉ける值の模式的な変化 (c) を示す。上下左 右一点扣きのデータ（丸印）の平均值を三角印の 位置に格納し（図(a)), 三角形のデータ群が揃っ た後, ×印のデータを補間によって求める（図 (b))。図(c)では, オリジナルデータが変化の多い 波状の線, 平滑化後の分布が一点鎖線, スケーリ ング後の分布がゆるやかな変化の実線で示してあ る。

図 7 に平滑化の効果を示す実例を揭げた。オリ ジナル（図(a)）はビデオ信号で, VTRテープを 再生して, 静止画としたものである。図(b)は平滑 化の手順を 3 回繰返したもの, 図(c)は画像データ 加算ニニット（インテグレータ）により32枚の画 像データの加算平均をとったものである。

\section{5. 等高線插入}

濃淡またはカラーの階段状階調で表示された画 像では, 定量的表示をより明確にするために, 各 階調の境界線に等高線を挿入するとよい場合が多 い(図 3 参照)。図 8 に等高線指入の概念を示す。 オリジナルデータは図(a) のなめらかな山形の分 布で示すように連続的である場合が多い。連続的 分布のままで, 指定する值を特定な色（通常白 色）で表示させると, 画像座標, 画像データがス テップ状であるため, 図(c)のように等高線が著 しく不連続になったり, 逆にかなり太い線になっ たりする。この不都合を避けるには, 值自身を図 (a)のようにあらかじめ階段状の值に変換し，その 後で例えば図（b）に示すアルゴリズムで白点を書 かせるとよい。すなわち, 着目点と右隣り, 下隣

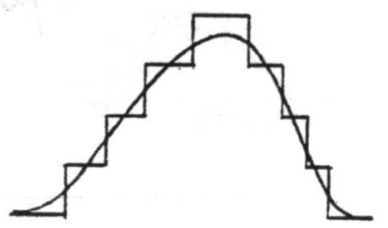

(a)

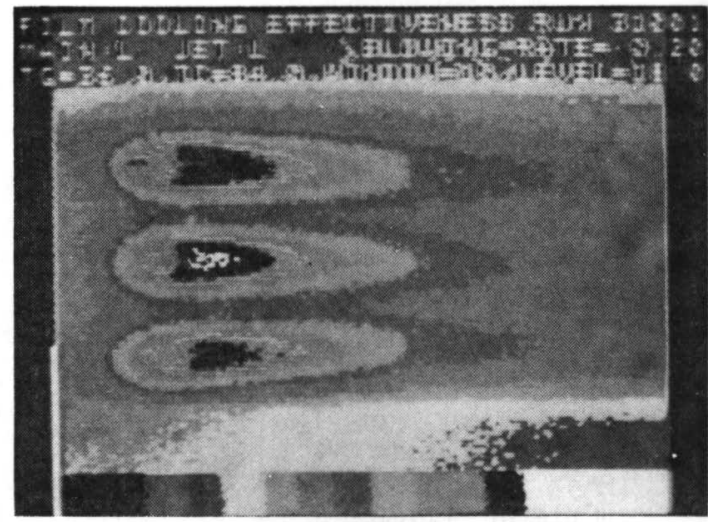

(a) 生データの一静止画像

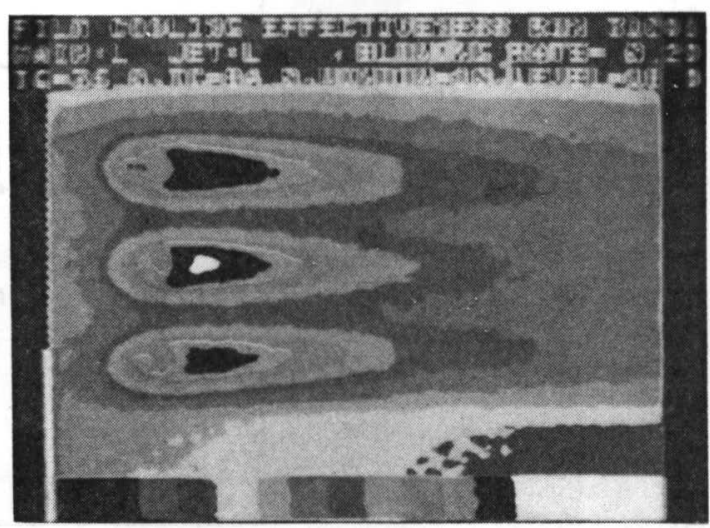

(b) ソフトウェア (図6)による平滑化

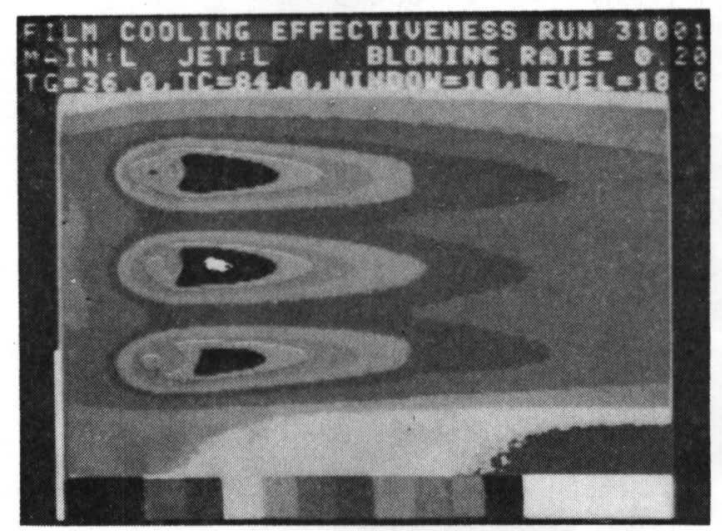

(c) インテグレータによる平滑化 図 7 画像の平滑化の実施例

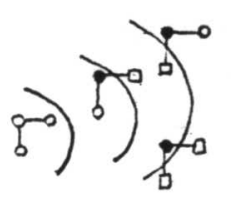

(b)

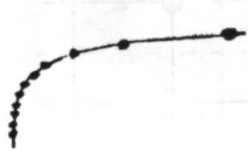

(c)

図 8 等高線挿入の概念 
りの三点の大きさを比較し，全部同 じならそのまま, 一点が他の二点の 値と異なるとき着目点を白くする。 ただし着目点の移動 (走査) 方向は 左から右，上から下とする。この方 法の例のように画像への等高線扱入 は, プロッタ線図のように格子状配 置のデータから直接等高線を書かせ る場合より格段に容易である。

注目する画像に执いて，分布の変 化が急激であるような領域が局所的 にあると，そこで書かれる等高線が 何本も隣接し，結局太くて白い領域 表示となって，オリジナルでは見ら れた変化の様相を消してしまうこと もあるので，等高線挿入がいつもよ いとは限らない。

\section{6. グラフ表示}

画像データから結果の解析をする際には, 様々 な值の抽出モードが考兄られる。なかでも特定な ライン上の分布をグラフ表示することは，多くの 場合に有用なモードである。画像表示では，プロ ッタによるグラフ書さとは異なって, 単一の曲線 ・折線が不連続となったり, 色表示の識別が不可 能になったりする。これらは用いているシステム の走査方式, 画素数, 周波数応答等に依存 $\iota$, 高 級なシステムでは問題にならない場合もある。

図 9 (a) 飞示す例は, この問題を避ける一つの 方法である。すなわち複数の分布曲線を重亦て示

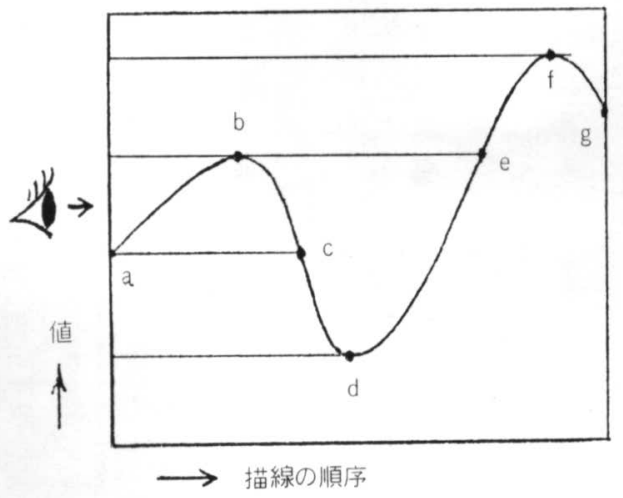

図11 隱線処理·裏面表示の概念

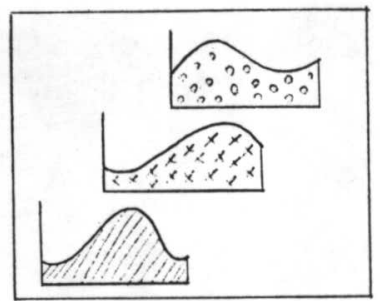

(b)

図9 グラフ表示方法の例

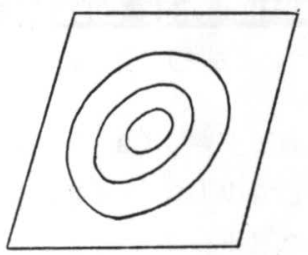

(b)

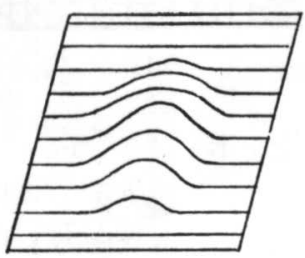

(c)

图10 三次元的（鳥钼図的）表示の概念

すのに, 一垂直方向に挴いて, ある値の位置から すぐ次に大きい值の位置までを，上位の值に対応 する色で塗りつぶすという手順を全部の垂直方向 に施す。この方法によれば，容易に特定ライン上 の分布が識別され, 特定位置で值の大きさの相互 比較ができる。しかし抽出するライン数が多くな ると判別が難しくなる。図(b)の方法は一ライン の分布毎に独立して表示をするもので，単純で見 易いが，グラフ表示が小さくなり, 值の相互比較 にも手間がかかる。

スカラー量の二次元分布を定性的に把握するの に，值を高さで表現し，三次元的（鳥観図的）に 表示する方法も有用である。図10にこの方法の概

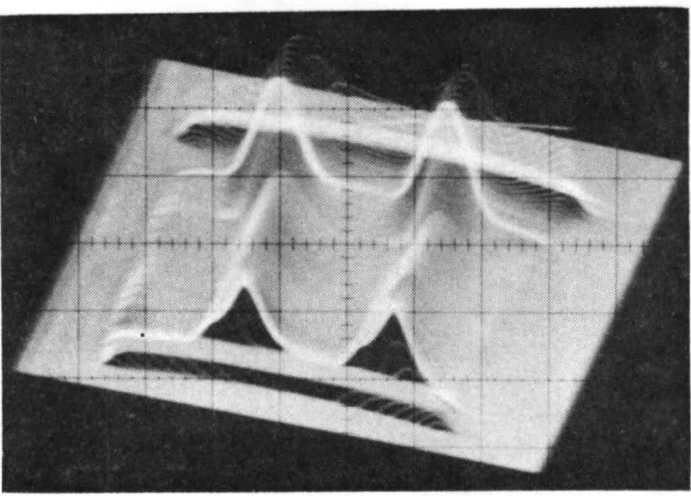

図12 プロセッサによる三次元的表示 


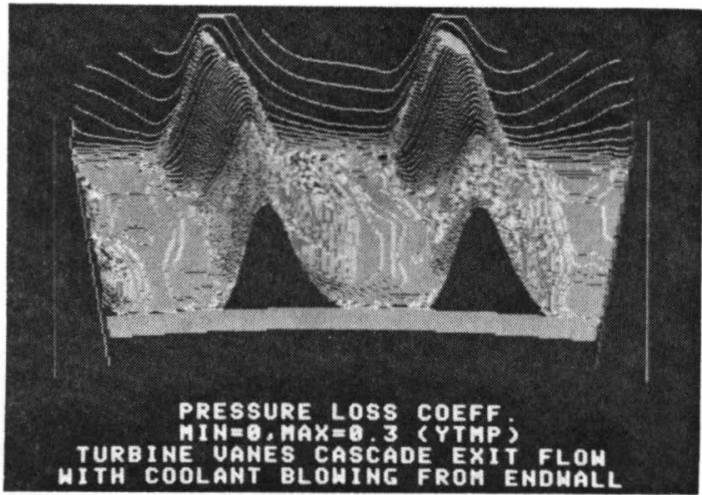

図13 ソフトゥェアによる三次元的表示

念を示す。与兄られた画像データ（a)を（b ) のよ らに, データをシフトして少し傾斜させた後, 図 (c)のよらに図の下方の水平線上の分布から順次 上方にグラフ書きを重ねる。ただし図11に示すよ らに一垂直線方向の分布で, $b-c, d-e, f-g$ の 部分は書かないようにする(隠線処理)。また $。$ d の部分は裏側であるから表示の色を変えるとよ い。抽出する水平線の位置は適当阔間をあける べきである。

図12, 図13は, 図 3 に示した画像データを, そ れぞれ, 実時間処理のできる三次元画像表示装置 とソフトウェアで作画した例である ${ }^{91,10)}$ 。この例 が示すように，值の高低が山と谷で表わされるの で, 分布の傾向が直感的に容易に理解される。

\section{7. あとがき}

画像表示に適切なアルゴリズムは，一般的に有 効な方法のみならず, 多くの場合, 個々の問題に 特有のものが必要となるので, 実際の作業に执い ては，知恵を絞る楽しさ，苦しさがつきまとう。 本稿はこれらアルゴリズムの一部の実施例を紹介 したにすぎないが，これらが，秀れた面白いアル ゴリズムを考光出すための一助となれば幸であ る。

\section{文献}

1) 白井·吉田, 流れの可視化, 4-14 (昭59-7), 349

2) 河合 · 廣瀬, 航空宇宙技術研究所報告, TR-816 (昭59-6)

3）神崎, 流れの可視化, 5-18 (昭60-7), 285

4) 小林, 日本機械学会誌, 88-799 (昭60-6), 644

5) 柳 ·進藤, 流れの可視化, 5-18 (昭60-7), 289

6) 吉田, 日本機械学会誌, 88-799 (昭60-6), 648

7) 西田, 同上, 639

8) Akima, H., Communications of the ACM, 17-1 (19 $74-1), 26$

9）三村他 4 名, 航空宇宙技術研究所資料, TM-514 (昭58-6)

10）吉田, 同上, TM-531（昭59-5） 